\title{
Does the Spleen Have a Function in Digestion? Medical History, Phylogenetic and Embryological Development of the Splenogastric System
}

\author{
Johannes Weinzirl ${ }^{a} \quad$ Tom Scheffers $^{a} \quad$ Lydia Garnitschnig $^{a} \quad$ Lukas Andrae $^{b}$ \\ Peter Heusser ${ }^{\text {a }}$ \\ ${ }^{a}$ Institute for Integrative Medicine, Faculty of Health, Witten/Herdecke University, Herdecke, Germany; ${ }^{\text {b Department }}$ \\ of Internal Medicine, Community Hospital Herdecke, Herdecke, Germany
}

Keywords

Spleen · Stomach · Digestion · Blood supply · Gastric vessels

\begin{abstract}
Background: Before the spleen was discovered to be a lymphatic blood organ, it had for centuries been considered to be a digestive organ. Concepts of a regulative, secretory and resorptive function in the digestive system were based mainly on a postulated connection between the stomach and the spleen. Splenogastric vascular connections have recently been rediscovered by modern surgery. Summary: To test the hypothesis that the spleen has a digestive function, this article reviews the literature focusing on the interaction between the spleen and the stomach. We examine the historical medical view of the spleen and stomach system and the reasons why a digestive function was abandoned in the 17 th and 18th centuries. We then review the rediscovery of the splenogastric system and the present-day state of knowledge (anatomical origin, variability, haemodynamics) and present it in terms of the phylogenetic and embryological development of the spleen and stomach system. Key Message: Splenogastric arteries and gastrosplenic veins form a portal system which directly connects the spleen and stomach parenchyma. Despite its mesodermal anlage, phylogenetically and embryologically the spleen is intimately inter-
\end{abstract}

karger@karger.com www.karger.com $/ \mathrm{cmr}$

Karger $\%$ BOPEN ACCESS
(C) 2020 The Author(s)

Published by S. Karger AG, Basel

This article is licensed under the Creative Commons AttributionNonCommercial-NoDerivatives 4.0 International License (CC BYNC-ND) (http://www.karger.com/Services/OpenAccessLicense). Usage and distribution for commercial purposes as well as any distribution of modified material requires written permission. connected with the entodermal stomach parenchyma but detaches from this in the course of development. Further study is required to establish whether the splenogastric system is merely an evolutive remnant or actually a part of a functioning spleen-stomach system as postulated in complementary and integrative medicine.

(C) 2020 The Author(s)

Published by S. Karger AG, Basel

Die Milz ein Verdauungsorgan? Zur Entwicklung des splenogastrischen Systems in Medizingeschichte, Phylogenese und Embryologie

\section{Schlüsselwörter}

Milz · Magen · Verdauung · Blutversorgung · Gastrische Gefässe

\section{Zusammenfassung}

Background: Bevor die Milz als lymphatisches Blutorgan entdeckt wurde, galt sie über Jahrhunderte hinweg als Verdauungsorgan. Konzepte einer regulativen, sekretorischen bzw. resorptiven Funktion im Verdauungssystem begründeten sich vor allem auf einer postulierten Verbindung zwischen Magen und Milz. Splenogastrische 
Gefäßverbindungen wurden in der modernen Chirurgie kürzlich wiederentdeckt. Summary: In diesem Review wird die Hypothese einer Verdauungsfunktion der Milz anhand einer Literatursuche geprüft und Ergebnisse für den Zusammenhang zwischen Milz und Magen dargestellt. Dabei erarbeiten wir zunächst die medizinhistorischen Konzepte des Milz-Magensystems und die Gründe, warum diese im 17. und 18. Jahrhundert aufgegeben wurden. Anschließend werden die Wiederentdeckung der splenogastrischen Gefäße und der heutige Kenntnisstand (Anatomischer Ursprung, Variabilität, Hämodynamik) zusammengefasst und hinsichtlich der phylogenetischen und embryologischen Entwicklung des Milz-Magensystems dargestellt. Key Message: Splenogastrische Arterien bzw. gastrosplenische Venen bilden ein Portalsystem, welches hilusunabhängig Milz- und Magenparenchym miteinander verbindet. Phylogenetisch und embryologisch zeigt sich die Milz trotz ihrer mesodermalen Anlage intim mit dem entodermalen Magenparenchym verwoben, löst sich im Lauf der Entwicklung jedoch davon los. Ob das splenogastrische System ein bloßes evolutives Überbleibsel darstellt oder tatsächlich sekretorische oder resorptive Funktionen eines von komplementären und integrativmedizinischen Methoden vertretenen MagenMilzsystems übernimmt, bedarf weiterer Studien.

(c) 2020 The Author(s)

Published by S. Karger AG, Basel

\section{Introduction}

The question of whether the spleen might have a role in the digestive system is one of the age-old riddles of medicine [1]. A great many philosophers, doctors and scientists have studied this neglected organ lying between the stomach and the diaphragm. They have described nutritional and excretory functions which had a significant influence on the diagnostic and therapeutic procedures in medicine. In the Eastern Zang-Fu teachings, the spleen (Yin element) was linked in a functional circle with the stomach (Yang organ) [2]. In Western medicine, the spleen was viewed as a chologenetic organ within the Hippocratic doctrine of the four humors [3]. These functions in nutrition and digestion were abandoned during the Medical Renaissance. Nowadays, the spleen is considered to be a lymphatic organ of the haematological and immunological systems. Its functions include the production, pooling and filtering of blood $[4,5]$.

Western naturopathy and Traditional Chinese Medicine continue to make use of concepts of the spleen as an organ of nutrition and digestion [6]. The integrative medical system of anthroposophical medicine $[7,8]$ also postulates a regulative nutritional function for the spleen [9]. However, integration of this functional concept with conventional medicine will only make sense if the corre- sponding anatomical and physiological basis is also elaborated in terms of an integrative organology.

We therefore pose the question of whether, in the light of conventional research, the spleen might indeed be described as an organ of nutrition and digestion. In this article, we investigate why the once chologenetic secretory organ was abandoned over the course of the 17th and 18 th centuries. We focus on recent studies from anatomy, embryology and phylogenetic development, which put these former findings into perspective. In particular, we discuss the rediscovery of vascular connections between the spleen and the stomach. A second article will be published separately with physiological and clinical phenomena exhibited by the spleen in relation to food intake. Postprandial dynamics of the spleen and the splanchnic system will be discussed in relation to functional hyposplenism, chronic inflammatory diseases and portal hypertension [10].

\section{Methods}

We searched MEDLINE by combining the search terms "spleen," "splen*" (in title) with the medical subject headings (MeSH) "Diet, Food, and Nutrition," "Digestive System and Oral Physiological Phenomena" and OR "Digestive System Diseases," as well as in combination with the search terms "gastric vessels," "splenogastr*" and "gastrosplen*” (search period March 2018). We selected relevant topics by screening the abstracts and reference lists. We worked through 5 major book publications on the spleen $[4,5,11-13]$ and communicated with 15 experts on anatomy, evolutionary biology, physiology, surgery, gastroenterology and anthroposophical medicine identified by their publications. We organised 2 scientific conferences at Witten/Herdecke University where we presented and discussed our results [14].

\section{Results}

\section{The Spleen in the History of Medicine}

In Western culture, it was Aristotle (384-322 BC) who, following his teacher Plato (427-347 BC) and based on the Corpus Hippocraticum, described a specific digestive function of the spleen [3]. Linked to the stomach by a "large net," the spleen drew "the superabundant moisture present in the stomach away." Galen of Pergamon (129199) described this netlike connection between the stomach and the spleen as a short vessel ("vas breve"), which served both to absorb the moisture and to secrete a tonifying and astringent "succus melancholicus." This fluid was believed to regulate the digestion, particularly appetite and peristalsis [1]. The purifying and secretory func- 
tion of the spleen as one of the main organs in the doctrine of the 4 humors (earth element/black bile) dominated medicine from then on.

In the 4th century Medical Compilations by Oribasius, we find the spleen as "a cleansing organ receiving the melancholic, thick and silty humors that are secreted by the liver. Thus, the spleen transmits the humors via a small vein into the stomach" [15]. In the writings of Meletius in the 8th century, "the spleen cleans the liver from the purulent and turbid humors that are rejected from the liver, to familiar food" [15]. Hildegard von Bingen (1098-1179) postulates: "Raw foods [...] cannot be easily concocted in the stomach because they have not previously been warmed. And so the bad humors of these foods penetrate [...] to the spleen and cause a painful swelling there" [16]. In addition, during the period of the Byzantine Empire, "the liver and the spleen contribute in digestion of food" [15]. This concept was adopted in Arabian medicine (600-1492) particularly by Avicenna: "The part [of black bile] that goes to the spleen is a fraction that the blood gives away for a necessity and a benefit. The necessity is a cleansing of the whole body from dregs and nourishment of the spleen. As for the benefit, it occurs when the black bile breaks down at the stomach mouth" [17]. From there, it spread its influence to the scholastic medicine of the late Middle Ages and the early Renaissance, such as in the textbook by Jacopo Berengario da Carpi (1522), where the spleen "helps the whole body to remove the waste from a large quantity of blood, by which laughter is produced, sometimes it creates blood, stimulates the appetite, supports digestion in the stomach" [18].

In the course of the Renaissance, the traditional and increasingly "literary and exegetic" [1] medicine turned towards empirical science, i.e., to the anatomical dissection of the human body. For the anatomy of the spleen, individuals of importance were Andreas Vesalius (15141564), William Harvey (1578-1657) and Marcello Malpighi (1628-1694). Vesalius revised the macroscopic anatomy, organ size and position and, in particular, the vasculature. He corrected over 200 inaccuracies of the traditional anatomy [3] including, crucially, that he was unable to find evidence of a galenic vessel between the spleen and the stomach: "they suppose a vein or channel from the spleen to be inserted into the upper mouth of the stomach [...], thus taught not by dissection but by fancy. I, of course, dare affirm nothing concerning this eructation of the residue of the spleen into the stomach and of its use" [3]. William Harvey revolutionised the understanding of the blood circulation, including the blood flow in the portal vein system. Jan de Wale (1604-1649) confirmed the arterial blood supply from the aorta to the spleen and the venous drainage from the spleen via the portal vein to the liver using ligation experiments. This disproved the traditional view that reabsorbed nutrients coming from the intestine or the liver would move directly to the spleen [1]. Marcello Malpighi broke new ground by penetrating the microscopic fine structure of the organ, described the trabecular and vascular systems and discovered the Malpighian corpuscles which carry his name. In his dissertation, the anatomist Henry Gray (1827-1861) wrote about the discovery of these Malpighian corpuscles: "This conclusion, deduced in the true spirit of the Baconian philosophy, was the first clear result given to the world of the complicated structure of this peculiar gland, a conclusion which completely overthrew the mystic and unphilosophical statements of his predecessors, and which was destined, together with his researches in other structures, to mark a new era in the history of physiology" [3].

What at first could only be voiced against the centuries old tradition in face of great opposition and conflict and in fear of the inquisition $[1,19]$ soon won through as a revolutionary doctrine: (a) the vascular connection between the spleen and the stomach postulated by Aristotle, Galen and others could not be verified anatomically; (b) the circulatory conditions in the portal vein system refute the idea that the spleen can receive nutrient-rich blood from the digestive system or the liver. It would therefore appear that the spleen is not capable of gastrointestinal resorption and secretion processes. The spleen is not a digestive organ but more an organ of the blood connected to the circulatory system and was henceforth studied in relation to its haematological and immunological functions.

Considering this turnaround, it is quite remarkable that the question of the vascular supply between the spleen and the stomach has been revised once again at the end of the 20th century. What failed to be detected in the anatomical examination of cadavers was rediscovered in modern spleen surgery.

\section{The Rediscovery of the Splenogastric Vessels}

In 1979, while carrying out splenectomies, the surgeon A. Petroianu observed that, after ligature of the splenic vascular pedicle, the spleen did not turn as cyanotic as expected, but remained reddish and supplied with blood at its upper pole [20]. He discovered small vessels inside the splenogastric ligament which connected the upper spleen parenchyma with the lower part of the stomach. The research group studied this blood supply unconnected to the hilum and developed the surgical procedure of a tissue-conserving splenectomy [11]. This procedure does not remove the entire spleen, but only the middle and lower parts of the parenchyma including the hilar vessels. The remaining tissue of the spleen's upper pole is still supplied from the stomach by the splenogastric vessels. This form of partial splenectomy has been performed successfully for the last 30 years for a number of indica- 
tions [21] along with a study of the functional anatomy of the splenogastric vessels.

These vessels between the stomach and spleen comprise a group of up to 14 delicate arterioles and venules which run inside the splenogastric ligament and at first appear to be collaterals or polar vessels of the upper short gastric vessels. They have been described and studied by a number of authors who were likewise concerned with the surgical objective of partial splenectomy [22-24]. In their systematic study, Farag et al. [25] in particular confirmed the existence of short gastric vessels passing between the stomach and the spleen. In $92 \%$ of human spleens $(n=59)$ and $100 \%$ of rat spleens $(n=18)$ they found at least one artery and one vein going directly into or emerging from the interior of the upper pole of the spleen. Within the stomach wall, these vessels originate either from the subserosal vascular plexus, the submucosal vascular plexus or both. They suggested a reclassification of the short gastric vessels into two groups, those communicating directly and those communicating nondirectly [26].

In microscopic and scintigraphic studies, Petroianu [11] found that the splenogastric arterioles start as intraparenchymal trabecular arteries and run to the gastric fundus, reaching the gastric submucosa. The gastric submucosal venules, on the other hand, form veins which run out of the stomach and end in the splenic parenchyma as sinusoidal capillaries. The physiological blood flow within these vessels depends on the pressure differences between the spleen and stomach wall. The arterioles follow a splenogastric flow, meaning that the spleen drains towards the stomach submucosa. Likewise, the flow in the veins is gastrosplenic, meaning that the bottom of the stomach drains toward the splenic parenchyma.

This physiological flow can reverse in the event of disease [11]. If, for instance, portal hypertension increases the venous pressure inside the spleen, the gastrosplenic veins reverse their flow and become splenogastric, causing venous congestion in the gastric fundus and encouraging the formation of oesophageal varices. Conversely, the arterial pressure in the spleen can drop, for instance if the flow from the splenic artery is obstructed by embolism or surgical ligature. The splenogastric arteries then reverse their physiological flow and become gastrosplenic, enabling an arterial supply based on a collateral circulation through the stomach tissue. In partial splenectomy, this is the basis for ensuring a blood supply to the remaining spleen tissue.

In summary, there are vascular connections between the spleen and stomach which are seldom mentioned in modern textbooks or only considered to be smaller divisions of the short gastric vessels. The distinctive histology and haemodynamics warrant a name of their own. Splenogastric arteries carry blood from the parenchyma of the

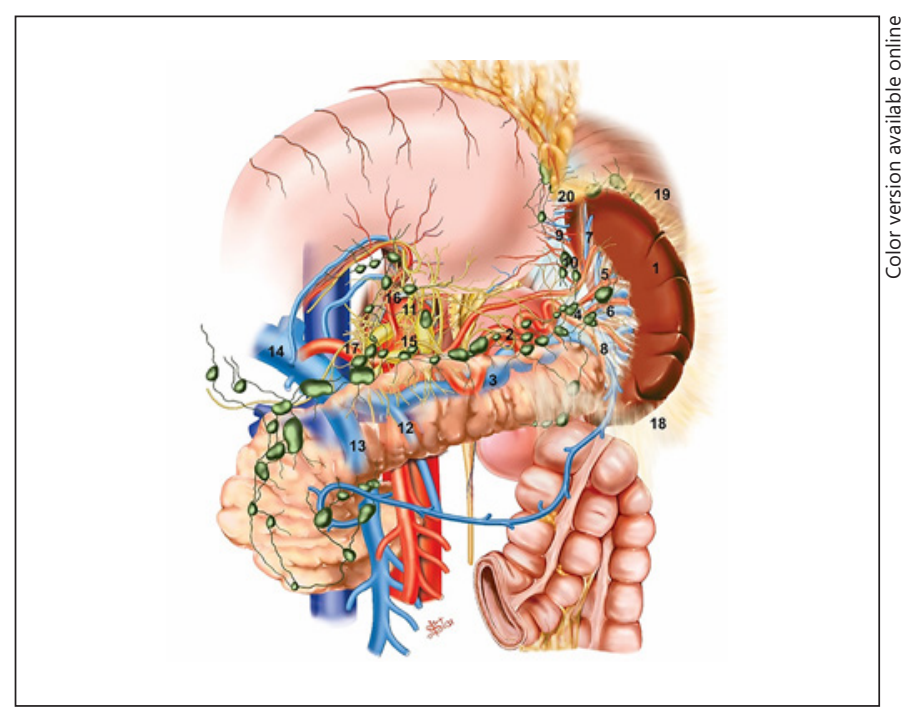

Fig. 1. Vascular anatomy of the spleen. Note the segmental arteries (\#5) branching from the splenic artery (\#2) immediately before the entry of the hilus (\#4), upper and lower polar vessels (\#7, \#8) and short gastric vessels (\#9). These can be distinguished from the splenogastric vessels which run inside the splenogastric ligament (\#20). Figure by I.G. Starling with kind permission from A. Petroianu in [47].

spleen to the tissue of the stomach. Conversely, the spleen receives gastrosplenic veins from the submucosal layer of the stomach and forms a small splenic portal system preceding the large liver portal system.

\section{The Spleen in Phylogenetic Development}

The relation between the spleen and the stomach becomes very distinct from a developmental perspective. Studies in comparative phylogeny show that in all vertebrates, the spleen has developed in intimate relation to the alimentary canal $[27,28]$. The lowest vertebrates, the $C y$ clostomes and Lungfish are considered to be living fossils and represent a range of about 400 million years [29]. Their spleen is organised as a lymphoid tissue that runs within the intestinal wall [30], first dispersed, then diffuse, then with segregations [31]. For example in the Australian Lungfish (Neoceratodus forsteri), the splenic tissue lies between the submucosa and tunica muscularis of the coiling intestines [32]. The elongated spleen forms a kind of central axis to which the spiral valve attaches.

The intestinal blood flow of this ancient species, $N$. forsteri, forms an enteric portal system, where the intestinal venous blood is first collected within the spleen before being forwarded to the liver via the splenic vein [31]. This splenic portal system was described by Purser for other Lungfish, such as Lepidosiren and Protopterus, as early as 1917 [33]. In Lepidosiren, the spleen concentrates in the uncoiled sheath of the foregut. In Protopterus, the spleen remains within the stomach wall throughout life [34]. 
Fig. 2. Spleen in human embryology: a Embryo (14 mm), approximately week 6: the homogeneous, light-coloured spleen (Mi) adheres to the mesenchyme of the posterior stomach wall. d Foetus $12.9 \mathrm{~cm}$, approximately 15-16 weeks: lateral view of the stomach (G) and segregating dark-coloured spleen $(\mathrm{Mi})$. Dissection and photo by Liebermann-Meffert taken with kind permission from [36]. Oe, Oesophagus; $\mathrm{Md}$, mesogastrium dorsale; Cma, greater curvature of the stomach; Py, pylorus; D, duodenum; G, stomach; Om, omentum majus; $\mathrm{C}$, colon.

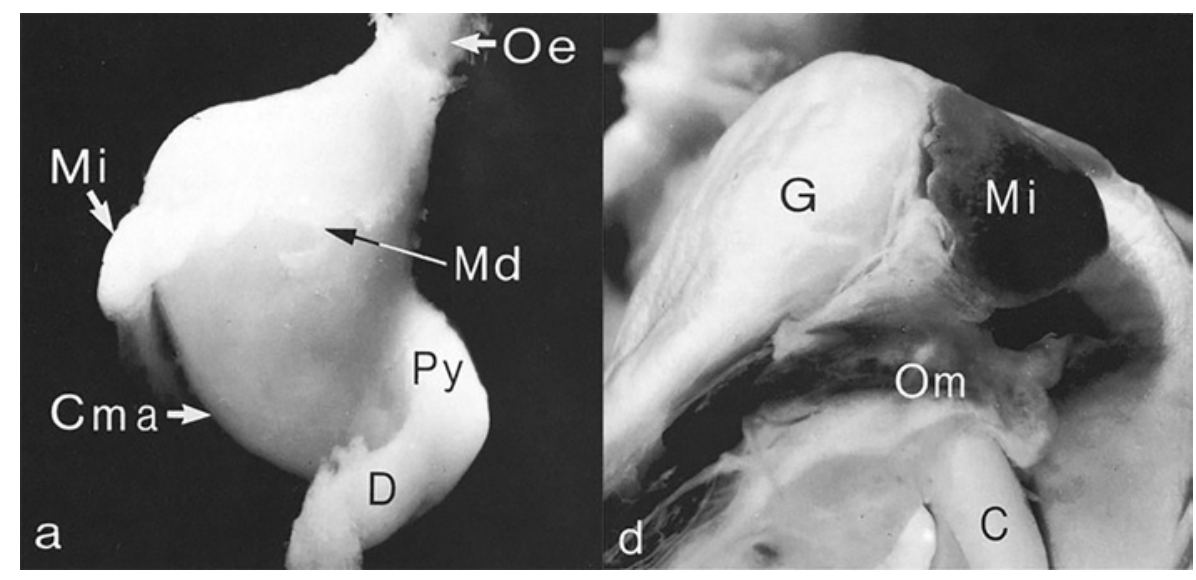

At the evolutionary stage represented by amphibians and reptiles, the elongated spleen tissue concentrates to become a discrete organ arising from an extra-enteric location, but still with variable shape and position $[27,28]$. In frogs (Anura) and turtles (Chelonia), a bean-shaped or globular spleen develops close to the caudal part of the mid-gut. In salamanders (Urodela) and snakes (Ophidia), we find a tongue-shaped spleen close to the foregut, stomach or pancreas [35]. Finally, in birds, mammals and humans, the spleen lies as a tongue- or bean-shaped organ almost always in the dorsal mesogastrium.

In view of this phylogenetic background, the rediscovered splenogastric system initially appears as a remnant of an older developmental stage of the spleen. It is remarkable that, in its original anlage, the spleen is not only anatomically intertwined with the digestive apparatus but, as a portal system with a purely venous supply, takes the nutrient-rich blood from the digestive system and transfers it to the liver.

\section{The Spleen in Embryological Development}

The development of the spleen originally entwined in the alimentary tract becomes more understandable when seen from an embryological perspective $[4,36]$. In humans, the splenic anlage can be detected around day 30 after fertilisation (E30). Within the dorsal mesogastrium, a condensed, non-vascularised mesenchyme can be differentiated from the loose mesenchyme of the stomach. At 2 months, the developing triangular-shaped spleen still adheres very closely to the dorsal stomach wall (Fig. 1a). As a result of the rotation of the stomach in the third month, the spleen separates and moves laterally upwards. Thus, the organ forms its mesenteric junction, the gastrolienal ligament. At the same time, dark-coloured centres appear and merge within the spleen as haematopoietic stem cells migrate into the spleen and initiate erythropoiesis (Fig. 2).

Remarkably, although the spleen is initially interwoven with the stomach mesenchyme, it does not derive from the fundamental morphological element of the gut, the endoderm. The spleen arises from the splanchnic mesoderm, something that was explicitly noted by the anatomist Ian M. Thompson back in 1927 [37]. Recent studies in molecular biology support a mesodermal origin of the spleen [38-40]. In mice, genes such as Tlx1 (Hox11), Bapx 1 and Wt1 have been shown to be required for spleen morphogenesis and expansion. Loss of these genes results in asplenia [38]. These splenic markers are expressed as early as E10.5 within the dorsal spleno-pancreatic region arising from the splanchnic mesoderm [39] and later in the developing spleen but not within the mesenchyme of the stomach [38]. At E9.5, Burn et al. [40] were also able to confirm that the splenic origin underlies the splanchnic mesodermal plate and that it is not derived from the stomach mesenchyme. Furthermore, in their culture experiments, they were able to show that the subsequent development of the spleen requires an interaction with the stomach. Removal of the anterior stomach resulted in disorganised spleen tissue expansion, and spleen precursor cells failed to move from the posterior greater curvature of the stomach towards the anterior lesser curvature.

\section{Discussion}

The cardinal question of a possible digestive function of the spleen refers to the origin of this organ in two aspects. First, the history of medicine points to the former organ of nutrition and secretion which lost its digestive function in the anatomical debates over the existence of a verifiable vascular connection between the stomach and the spleen. Second, we follow the phylogenetic and embryological source of the spleen initially formed within the gut and later separated as a primordial venous portal system between the gastrointestinal system and the liver. In early organogenesis, the interaction of the mesodermal primordium of the spleen with the endodermal stomach parenchyma seems necessary. Later on, the spleen separates from the digestive system and, due to vascularisation of the splenic artery, be- 
comes a blood organ with the development of its immunological and hematopoietic functions.

The rediscovery of direct-communicating vessels between the stomach and the spleen sheds light on the centuries-old debates. Splenogastric arterioles and gastrosplenic venules provide the anatomical basis for the possibility of secretory and resorptive functions between the spleen and the stomach. As substances such as short- and medium-chain fatty acids [41, 42], alcohol [43], nicotine [44], caffeine [45] and pharmaceuticals [46] have been shown to be absorbed into the mucosa of the stomach, these substances might be transported directly to the spleen. Conversely, if blood flows from the spleen into the submucosal layers of the stomach, the hypothesis of a secretory or endocrine function of the spleen is possible. These considerations, while preliminary, suggest that the spleen might have a role within nutrition and digestion.

\section{Conclusion}

The traditional view of a spleen-stomach system can be confirmed by modern anatomy and surgery in terms of a verifiable vessel connection between these organs. Further empirical studies are required to determine whether the splenogastric vessels are simply an evolutionary legacy or whether they actually perform a functional role in the digestive system as postulated in complementary and integrative medicine.

\section{Acknowledgements}

We wish to thank A. Farag, A. Husemann, A. Petroianu and W. Schad for helpful discussion.

\section{Statement of Ethics}

The authors have no ethical conflicts to disclose.

\section{Disclosure Statement}

The authors declare that they have no conflict of interest. The study was not influenced by the foundations that provided financial support.

\section{Funding Sources}

We gratefully acknowledge the financial support of the Christophorus Stiftung and the Software AG Stiftung.

\section{Author Contributions}

All authors made substantial contributions to the conception of this article. J.W. and L.G. prepared the medical history part. J.W. and T.S. prepared the phylogenetic and embryologic development. J.W. wrote the final manuscript, which was reviewed, edited and revised by T.S., L.A. and P.H.

\section{References}

1 Tischendorf F. Zur Geschichte der Milzforschung: Rückblick und Ausblick. Berlin, Heidelberg: Springer-Verlag; 1970. https://doi. org/10.1007/978-3-642-48115-4.

2 Patwardhan B, Warude D, Pushpangadan P, Bhatt N. Ayurveda and traditional Chinese medicine: a comparative overview. Evid Based Complement Alternat Med. 2005 Dec; 2(4):465-73.

3 McClusky DA 3rd, Skandalakis LJ, Colborn GL, Skandalakis JE. Tribute to a triad: history of splenic anatomy, physiology, and surgery-part 1. World J Surg. 1999 Mar;23(3): 311-25.

4 Tischendorf F. Die Milz. Berlin, Heidelberg: Springer; 1969.

5 Bowdler AJ, editor. The Complete Spleen. Structure, Function, and Clinical Disorders. Totowa, NJ: Humana Press; 2002. https://doi. org/10.1007/978-1-59259-124-4.

6 Yang X, Jia C. Understanding association of spleen system with earth on traditional Chinese medicine theory. J Tradit Chin Med. 2013 Feb;33(1):134-6.

7 Heusser P. Anthroposophy and Science: an Introduction. 1. New York: Peter Lang; 2016. https://doi.org/10.3726/978-3-653-06753-8.

8 Kienle GS, Albonico HU, Baars E, Hamre HJ, Zimmermann P, Kiene H. Anthroposophic medicine: an integrative medical system originating in Europe. Glob Adv Health Med. 2013 Nov;2(6):20-31.

9 Weinzirl J, Scheffers T, Garnitschnig L, Heusser P. Die Milz in Natur- und Geisteswissenschaft. Merkurstab. 2018;71(2):110-9.

10 Weinzirl J, Garnitschnig L, Scheffers T, Andrae L, Heusser P. Digestion. Forthcoming 2020.

11 Moynihan B. The Spleen and Some of Its Diseases: Being the Bradshaw Lecture of the Royal College of Surgeons of England. Oxford: Butterworth-Heinemann; 1920.

12 Petroianu A. The Spleen. Minas Gerais: Bentham Science Publishers; 2011.

13 Lennert K, Harms D, editors. Die Milz: Struktur, Funktion, Pathologie, Klinik, Therapie. 1st ed. Berlin, Heidelberg: Springer-Verlag; 1970. https://doi.org/10.1007/978-3-642-92998-4.

14 Kolloquium: Wesen und Funktion des Milzorgans aus naturwissenschaftlicher und geisteswissenschaftlicher Perspektive. Universität Witten/Herdecke. 2013 Nov 9./10. and 2014 Dec 6.

15 Paraskevas GK, Koutsouflianiotis KN, Nitsa Z, Demesticha T, Skandalakis P. Knowledge of the anatomy and physiology of the spleen throughout Antiquity and the Early Middle Ages. Anat Sci Int. 2016 Jan;91(1):43-55.
16 von Bingen $H$. Heilwissen. Therapeutisches Monatsheft, 16. Jahrgang. Berlin: 1902.

17 Mones AA, Hakima A, Marc M. Avicenna's Medicine: A New Translation of the 11thCentury Canon with Practical Applications for Integrative Health Care. Inner Traditions/ Bear \& Co; 2013.

18 da Carpi JB. Isagogae Breves et Exactissimae in Anatomia Humani Corporis. Henricus Sybold; 1530.

19 Wear A. The spleen in renaissance anatomy. Med Hist. 1977 Jan;21(1):43-60.

20 Petroianu A, Petroianu S. Anatomy of splenogastric vessels in patients with schistosomal portal hypertension. Clin Anat. 1994;7(2):803.

21 Petroianu A, da Silva RG, Simal CJ, de Carvalho DG, da Silva RA. Late postoperative follow-up of patients submitted to subtotal splenectomy. Am Surg. 1997 Aug;63(8): 735-40.

22 Keramidas DC, Ittleman FP. The ligation of the splenic artery in the treatment of traumatic rupture of the spleen. J Trauma Acute Care Surg. 1980 Mar;20(3):267.

23 Al-Hayani A. Study of the polar arteries supplying the spleen and their significance in its viability. J Rawalpindi Med Coll JRMC. 2007; 11(2):2. 
24 Skandalakis JE, Colborn GL, Foster RS, Weidman TA, Skandalakis LJ, Skandalakis PN. Surgical Anatomy: The Embryologic and Anatomic Basis of Modern Surgery. Athens, London: Surgery; 2007.

25 Farag A, Shoukry A, Nasr SE. A new option for splenic preservation in normal sized spleen based on preserved histology and phagocytic function of the upper pole using upper short gastric vessels. Am J Surg. 1994 Sep;168(3):257-61.

26 Scher KS. Splenic preservation using upper short gastric vessels. Am J Surg. 1995 Sep; 170(3):304.

27 Murata H. Comparative studies of the spleen in submammalian vertebrates. Bull Yamaguchi Med Sch. 1959;6(3).

28 Tischendorf F. On the evolution of the spleen. Experientia. 1985 Feb;41(2):145-52.

29 Jorgensen JM, Joss J, editors. The Biology of Lungfishes. CRC Press; 2016. https://doi. org/10.1201/b10357.

30 Fänge R, Nilsson S. The fish spleen: structure and function. Experientia. 1985 Feb;41(2): 152-8.

31 Saito H. The development of the spleen in the Australian lungfish, Neoceratodus forsteri Krefft, with special reference to its relationship to the "gastro"-enteric vasculature. Am J Anat. 1984 Mar;169(3):337-60

32 Rafn S, Wingstrand K. Structure of intestine, pancreas, and spleen of the Australian lungfish, Neoceratodus forsteri (Krefft). Zool Scr. 1981;10(3):223-39.
33 Purser G. Memoirs: The early development of the spleen of Lepidosiren and Protopterus. Q J Microsc Sci. 1917;2(246):231-41.

34 Icardo JM, Wong WP, Colvee E, Loong AM, Ip YK. The anatomy of the gastrointestinal tract of the African lungfish, Protopterus annectens. Anat Rec (Hoboken). 2010 Jul; 293(7):1146-54

35 Dabrowski Z, Sano Martins IS, Tabarowski Z, Witkowska-Pelc E, Spadacci Morena DD, Spodaryk K, et al. Haematopoiesis in snakes (Ophidia) in early postnatal development. Cell Tissue Res. 2007 May;328(2):291-9.

36 Hinrichsen KV, Beier HM, Breucker $\mathrm{H}$, Christ B, Duncker HR, Dvorak M, et al. Humanembryologie. Lehrbuch und Atlas der vorgeburtlichen Entwicklung des Menschen. Berlin: Springer Berlin; 2014.

37 Thompson IM. What is the Significance of the Spleen?: An Anatomical and Physiological Review. Can Med Assoc J. 1926 Jul;16(7):813-8.

38 Brendolan A, Rosado MM, Carsetti R, Selleri L, Dear TN. Development and function of the mammalian spleen. BioEssays. 2007 Feb; 29(2):166-77.

39 Hecksher-Sørensen J, Watson RP, Lettice LA, Serup P, Eley L, De Angelis C, et al. The splanchnic mesodermal plate directs spleen and pancreatic laterality, and is regulated by Bapx1/Nkx3.2. Development. 2004 Oct; 131(19):4665-75.
40 Burn SF, Boot MJ, de Angelis C, Doohan R, Arques CG, Torres M, et al. The dynamics of spleen morphogenesis. Dev Biol. 2008 Jun; 318(2):303-11.

41 Carey MC, Small DM, Bliss CM. Lipid digestion and absorption. Annu Rev Physiol. 1983; 45(1):651-77.

42 Faber J, Goldstein R, Blondheim O, Stankiewicz H, Darwashi A, Bar-Maor JA, et al. Absorption of medium chain triglycerides in the stomach of the human infant. J Pediatr Gastroenterol Nutr. 1988 Mar-Apr;7(2):189-95.

43 Cooke AR. The stimultaneous emptying and absorption of ethanol from the human stomach. Am J Dig Dis. 1970 May;15(5):449-54.

44 Ivey KJ, Triggs EJ. Absorption of nicotine by the human stomach and its effect on gastric ion fluxes and potential difference. Am J Dig Dis. 1978 Sep;23(9):809-14.

45 Heckman MA, Weil J, Gonzalez de Mejia E. Caffeine (1, 3, 7-trimethylxanthine) in foods: a comprehensive review on consumption, functionality, safety, and regulatory matters. J Food Sci. 2010 Apr;75(3):R77-87.

46 Hogben CA, Schanker LS, Tocco DJ, Brodie BB. Absorption of drugs from the stomach. II. The human. J Pharmacol Exp Ther. 1957 Aug; 120(4):540-5.

47 Standring S. Gray's Anatomy: the Anatomical Basis of Clinical Practice. 41st ed. New York: Elsevier Limited; 2016. 